\title{
Evaluation of Quality of Life and Care Needs of Turkish Patients Undergoing Hematopoietic Stem Cell Transplantation
}

\author{
Neslisah Yasar ${ }^{1}$ and Semiha Akin ${ }^{2}$ \\ ${ }^{1}$ Beykent University Vocational School, Cumhuriyet Mah. Şimşek Sok., Beykent, Büyükçekmece, 34522 Istanbul, Turkey \\ ${ }^{2}$ Istanbul Bilim University Florence Nightingale Hospital School of Nursing, Yazarlar Sokak No. 17, Esentepe, \\ Şişli, 34394 Istanbul, Turkey \\ Correspondence should be addressed to Semiha Akin; semihaakin@yahoo.com
}

Received 5 July 2016; Revised 5 November 2016; Accepted 27 November 2016

Academic Editor: Kathleen Finlayson

Copyright (c) 2016 N. Yasar and S. Akin. This is an open access article distributed under the Creative Commons Attribution License, which permits unrestricted use, distribution, and reproduction in any medium, provided the original work is properly cited.

\begin{abstract}
This descriptive study explored the quality of life and care needs of Turkish patients who underwent hematopoietic stem cell transplantation. The study sample consisted of 100 hematopoietic stem cell transplant patients. Their quality of life was assessed using Functional Assessment of Cancer Therapy-Bone Marrow Transplant Scale. The mean patient age was $44.99 \pm 13.92$ years. Changes in sexual functions, loss of hair, loss of taste, loss of appetite, and sleep disturbances were the most common symptoms. The quality of life of transplant patients was moderately affected; the functional well-being and social/family well-being subscales were the most adversely and least negatively affected $(12.13 \pm 6.88)$ dimensions, respectively. Being female, being between 50 and 59 years of age, being single, having a chronic disease, and having a history of hospitalization were associated with lower quality of life scores. Interventions to improve functional status, physical well-being, and emotional status of patients during the transplantation process may help patients cope with treatment-related impairments more effectively. Frequent screening and management of patient symptoms in order to help patients adapt to life following allogeneic hematopoietic stem cell transplantation are crucial for meeting care needs and developing strategies to improve their quality of life.
\end{abstract}

\section{Introduction}

Hematopoietic stem cell transplantation is frequently used for treatment of many malign and benign diseases, particularly aplastic anaemia and thalassemia. Although it yields positive results in the treatment of many diseases, hematopoietic cell transplantation also leads to significant mortality and morbidity [1]. Because of its positive effects on life expectancy and quality of life, the number of hematopoietic stem cell transplantation centers and patients who benefit from this treatment is rapidly increasing. A total of 1,678 autologous, 702 related allogeneic hematopoietic, 129 unrelated allogeneic hematopoietic, 122 haploidentical, and 953 allogeneic hematopoietic stem cell transplantations were performed in Turkey in 2015 [2].

After hematopoietic stem cell transplantation, quality of life may be adversely affected because of autoimmune and hematologic complications, pulmonary diseases, cardiovascular diseases, ocular complications, musculoskeletal problems, oral mucosa and dental problems, genitourinary system problems, gastrointestinal and hepatic complications, metabolic problems, nervous system disorders, secondary malignancies, and psychosocial problems [3-5]. Prevention of infection and late complications are the primary treatment and care priorities after hematopoietic stem cell transplantation. Treatment and care requirements during and after transplantation vary depending on patient performance status, age, disease stage, conditioning regimen, transplantation type (autologous or allogeneic), treatment, and transplantation-associated complications $[1,6]$. Studies have demonstrated that the quality of life among patients who undergo hematopoietic stem cell transplantation is affected negatively on many levels and that they require support for symptom control [7-14].

Patients undergoing hematopoietic stem cell transplantation require assistance with symptom control and for dealing with side effects in order to avoid negative effects of their physical condition, social/family status, emotional status, 
functional status, and additional detrimental effects on their quality of life. For successful hematopoietic stem cell transplantation and prevention of complications, the information and support needs of the patient and their family should be determined before the patient is discharged. Studies on the difficulties and problems faced by patients undergoing hematopoietic stem cell transplantation will help to improve patient quality of life and better meet their needs in the early stages of the postdischarge period. Therefore, this descriptive study evaluated patient care needs and quality of life after discharge following hematopoietic stem cell transplantation in order to identify the variables associated with quality of life.

\section{Methods}

2.1. Setting. The study was conducted in the hematopoietic stem cell transplant service of a university hospital.

2.2. Study Questions. This study assessed the following three questions.

(1) Does hematopoietic stem cell transplantation affect patient quality of life?

(2) What are the support needs and the symptoms experienced by patients after hematopoietic stem cell transplantation?

(3) What are the sociodemographic, health-related, and disease-related characteristics of the disease of patients who are undergoing hematopoietic stem cell transplantation?

\subsection{Dependent and Independent Variables}

(i) Dependent variables are quality of life, symptoms, and care needs.

(ii) Independent variables are gender, age, educational status, history of chronic disease, type of transplant, period of transplantation, and hospitalization history.

2.4. Study Population and Sample. The study population included adult patients undergoing allogeneic and autologous hematopoietic stem cell transplantation at a university hospital. The study aimed to reach the entire target population.

Between March and October 2015 a total of 104 patients were assessed. Patients included in the study were those who (1) underwent hematopoietic stem cell transplantation (allogeneic or autologous); (2) were $\geq 18$ years of age; (3) could understand, read, and write Turkish; (4) whose general condition made them eligible for participation in the study; and (5) agreed to participate in the study. Three patients were excluded because they were in the terminal stage of disease, and one was excluded because he did not understand Turkish. Thus, 100 patients met the inclusion criteria. This study used convenience sampling, one of the nonprobability sampling methods.

2.5. Ethical Issues. Ethical Committee (Ethical Committee Decision number 13.01.2015/27-192) and institutional approval were received to perform the study. Data were col- lected between March and October 2015 from the hematopoietic stem cell transplantation services center. Permission was granted to use patient's quality of life scores from the Functional Assessment of Cancer Therapy-Bone Marrow Transplant (FACT-BMT, 4th Version) questionnaire.

2.6. Data Collection. Data were collected by face-to-face interview, as described below. Interviews were held in the patients' rooms. Information about disease and treatment was collected from patient medical reports. Patient interviews were completed within 20-25 minutes.

2.7. Data Collection Tools. Patients provided written informed consent. Features related to sociodemographic and disease characteristics were collected using the patient information form. The symptom checklist asked the patients to provide information about the frequency of their symptoms. In the FACT-BMT, individuals were asked to answer the questions regarding their status in the last 7 days.

(1) Patient information form contained questions to determine the personal, disease, and treatmentrelated characteristics.

(2) Symptom checklist was developed by the investigators to determine the frequency of symptoms experienced during the treatment process. Symptoms which could be related to the treatment (hair loss, weight loss, constipation, diarrhea, loss of taste, headache, dizziness, itching, leg-muscle-bone pain, sleep disorders, difficulty concentrating, decrease in sexual function, lack of appetite, and nausea-vomiting) were included in this form. Each symptom was rated from 1 to 5 points ("always" $\rightarrow 5$ points, "often" $\rightarrow 4$ points, "sometimes" $\rightarrow 3$ points, "rarely" $\rightarrow 2$ points, and "never" $\rightarrow 1$ point).

(3) FACT-BMT scale, multidimensional, health-related quality of life scale, is used to evaluate the quality of life of patients who have undergone hematopoietic stem cell transplantation. The scale consists of five dimensions and 47 items in total. The subdimensions of the fourth version include (1) physical well-being, (2) social/family well-being, (3) emotional wellbeing, (4) functional well-being, and (5) additional concerns. The fifth subdimension of the scale, "Additional Concerns," consists of 23 questions to determine side effects in Bone Marrow Transplant Subscale (BMTS) patients who might experience physical and psychological problems and treatment side effects [15]. The minimum and maximum FACT-BMT scores are 0 and 148, respectively. Higher scores indicate better quality of life. The validity and reliability of the FACT-BMT Scale were reported by McQuellon et al. in 1997. The overall reliability coefficient (Cronbach's alpha) of the Turkish version of the scale in this study was 0.90 .

2.8. Statistical Analysis and Evaluation of Data. Data were evaluated using SPSS 16.0. Descriptive statistics such as 
arithmetic averages, standard deviations, and percentages were used to analyze the data frequency. Parametric or nonparametric tests were used depending on the data characteristics and distribution in order to compare total average scores and variables. Spearman's correlation analysis and Pearson correlation tests were used for correlation analysis. $p$ values less than 0.05 were considered statistically significant. The normality of the data was tested using the one-sample Kolmogorov Smirnov test; since significance levels were less than 0.05 , nonparametric tests were used for further analyses. Among these, Mann-Whitney $U$ and KruskalWallis tests were used for comparison of two and more than two independent variables, respectively.

\section{Results}

3.1. Personal and Treatment-Related Characteristics. The average age of the subjects in this study was $44.99 \pm 13.92$ years, and $54 \%$ were married men. Among the subjects included in the study, $27 \%$ had graduated from high school and $22 \%$ had bachelor's degrees. Twenty percent of patients undergoing hematopoietic stem cell transplantation were undergoing treatment for chronic disease. Most of them (59\%) continued acute-phase treatment following transplantation. Most of the patients $(71 \%, n=71)$ underwent allogeneic hematopoietic stem cell transplantation, and 29 (29\%) patients underwent autologous hematopoietic stem cell transplantation. The average time elapsed since transplantation was $3.99 \pm 5.27$ months (range: $1-34$ months). Hospitalization following discharge occurred in $38 \%$ of patients who underwent hematopoietic stem cell transplantation (Table 1).

3.2. Symptoms and Support Needs. The most common complaints of patients following hematopoietic stem cell transplantation were decreased sexual function $(n=59)$, hair loss $(n=43)$, and loss of taste $(n=37)$. Most of the patients reported not experiencing dizziness $(n=47)$, itching $(n=$ $44)$, and bone pain $(n=36)$ (Table 2$)$.

Patients reported difficulty in attending social activities $(33 \%)$ and fulfilling of social roles and responsibilities (31\%). Nearly one-quarter of the patients (23\%) reported that they felt alone; they also had concerns about dealing with treatment side effects (19\%) and using medicine after discharge $(13 \%)$. The patients had received training on protection against infection (60\%), activities of daily living after discharge (55\%), nutrition (46\%), catheter care (40\%), medication side effects (30\%), and graft-versus-host disease (27\%).

3.3. Quality of Life Scores. The total FACT-BMT scale score $(81.38 \pm 21.91)$ suggests a moderate effect on patient quality of life, with the physical well-being most affected (12.13 \pm 6.88). Furthermore, the emotional and functional well-being of transplant patients was moderately affected $(12.70 \pm 6.41$ and $13.95 \pm 4.61$, resp.). The BMTS subdimension score was $21.79 \pm 6.61$ (Table 3 ).

The highest and lowest scores were given to the items "I have confidence in my nurse(s)" and "I regret having the bone marrow transplant," respectively (Table 3).
TABLE 1: Demographic and treatment-related characteristics of patients who underwent hematopoietic stem cell transplantation $(n=100)$.

\begin{tabular}{|c|c|c|}
\hline Variables & $n$ & $\%$ \\
\hline Mea & \multicolumn{2}{|c|}{$\begin{array}{c}\text { Mean } \pm \text { sd } 44.99 \pm 13.93 \text { (range: } \\
20-69)\end{array}$} \\
\hline \multicolumn{3}{|l|}{ Gender } \\
\hline Male & 54 & 54 \\
\hline Female & 46 & 46 \\
\hline \multicolumn{3}{|l|}{ Age group } \\
\hline $20-29$ & 16 & 16 \\
\hline $30-39$ & 21 & 21 \\
\hline $40-49$ & 19 & 19 \\
\hline $50-59$ & 28 & 28 \\
\hline $60-69$ & 16 & 16 \\
\hline \multicolumn{3}{|l|}{ Marital status } \\
\hline Married & 70 & 70 \\
\hline Single & 30 & 30 \\
\hline \multicolumn{3}{|l|}{ Profession } \\
\hline Not working currently & 24 & 24 \\
\hline Housewife & 23 & 23 \\
\hline Clerk & 14 & 14 \\
\hline Self-employed & 14 & 14 \\
\hline Retired & 14 & 14 \\
\hline Worker & 11 & 11 \\
\hline \multicolumn{3}{|l|}{ Types of family } \\
\hline Elementary family & 73 & 73 \\
\hline Traditional, large family & 18 & 18 \\
\hline Broken family & 9 & 9 \\
\hline \multicolumn{3}{|l|}{ History of chronic disease } \\
\hline No & 80 & 80 \\
\hline Yes (diabetes, etc.) & 20 & 20 \\
\hline \multicolumn{3}{|l|}{ Perceived health status } \\
\hline “Bad” (0-3 score) & 42 & 42 \\
\hline "Moderate" (4-6 score) & 46 & 46 \\
\hline “Good” (7-10 score) & 12 & 12 \\
\hline \multicolumn{3}{|l|}{ Frequency of medical checkups } \\
\hline $\begin{array}{l}\text { In case of presence of any symptom or } \\
\text { problems }\end{array}$ & 29 & 29 \\
\hline $\begin{array}{l}\text { According to physician's } \\
\text { recommendations }\end{array}$ & 24 & 24 \\
\hline No regular medical checkups & 18 & 18 \\
\hline Once in six months & 15 & 15 \\
\hline Once in three months & 10 & 10 \\
\hline Once in a year & 4 & 4 \\
\hline \multicolumn{3}{|l|}{ Type of transplantation } \\
\hline $\begin{array}{l}\text { Allogeneic hematopoietic stem cell } \\
\text { transplantation }\end{array}$ & 71 & 71 \\
\hline $\begin{array}{l}\text { Autologous hematopoietic stem cell } \\
\text { transplantation }\end{array}$ & 29 & 29 \\
\hline
\end{tabular}


TABLE 1: Continued.

\begin{tabular}{lll}
\hline Variables & $n$ & $\%$ \\
\hline $\begin{array}{l}\text { Indications for hematopoietic stem cell } \\
\text { transplantation }\end{array}$ & 26 & 26 \\
Acute myeloid leukemia & 22 & 22 \\
Acute lymphoblastic leukemia & 11 & 11 \\
Hodgkin's disease & 11 & 11 \\
Non-Hodgkin lymphoma & 6 & 6 \\
Chronic myeloid leukemia & 5 & 5 \\
Dysmyelopoietic syndrome & 5 & 5 \\
Severe immunodeficiencies & 4 & 4 \\
Autoimmune cytopenias & 1 & 1 \\
Multiple myeloma & 1 & 1 \\
Light chain deposition disease & 8 & 8 \\
Other disorders (bone marrow aplasia, & & \\
etc.) & & \\
Current treatment & & \\
Acute-phase treatment following & 59 & 59 \\
transplantation & 29 & 29 \\
Outpatient follow-up & 12 & 12 \\
Treatment of transplantation-related & & \\
complications & & \\
History of hospitalization after & & \\
transplantation & & \\
No & & \\
Yes (infection, chronic graft-versus-host & & \\
disease, etc.) & & \\
\hline & & \\
\hline
\end{tabular}

3.4. Comparison of Quality of Life Average Scale Scores Based on Personal Characteristics. FACT-BMT scale scores were compared based on the gender of patients who had undergone stem cell transplantation. Statistically significant differences were found only between scores of the emotional well-being subdimension $(p<0.05)$. The emotional wellbeing subdimension scores were significantly higher in male patients than in females patients $\left(Z_{\mathrm{mwu}}=-3.262, p=0.001\right)$ (Table 4).

Statistically significant differences based on age were found only between social life and family well-being subdimensions $(p<0.05)$. The social life and family well-being subdimension scores $(22.82 \pm 5.43)$ among patients 60-69 years of age were higher than those of patients 50-59 years of age $(19.70 \pm 4.27)\left(\chi_{\mathrm{kw}}^{2}=10.305, p=0.036\right)$. A very low, statistically significant negative correlation was found between FACT-BMT scores for physical well-being subscale and age $\left(r_{s}=-0.22, p<0.05\right)$.

Statistically significant differences in BMTS were observed for marital status $(p<0.05)$. The subscale score of married patients $(22.59 \pm 6.81)$ is significantly higher than that of single patients $(19.93 \pm 5.80)\left(Z_{\mathrm{mwu}}=-2.013\right.$, $p=0.044)$.

Only the social life and family well-being subscale differed significantly for patient family types $(p<0.05)$. The subscale scores were higher $(23.66 \pm 3.35)$ in patients with traditional, large families than the scores of patients with "elementary" or "broken families" $(20.33 \pm 4.02$ and $19.00 \pm$ 5.59 , resp.) $\left(\chi_{\mathrm{kw}}^{2}=12.024, p=0.002\right)$ (Table 4$)$.

Based on chronic disease history, statistically significant differences were also observed for emotional well-being subscale $(p<0.05)$. Scores were higher in patients without chronic disease $(13.44 \pm 6.25)$ than in patients with chronic disease $(9.75 \pm 6.31)\left(Z_{\text {mwu }}=-2.270, p=0.023\right)$.

There were also significant differences in physical wellbeing, functional well-being, FACT-G dimensions, and FACT-BMT scale scores based on the health perception of patients in the last year. The physical well-being, functional well-being, FACT-G, TOI (Trial Outcome Index) scores, and FACT-BMT scale scores were higher among patients who reported their state of health as "good" or "moderate" compared to patients who reported their state of health as "bad" (Table 4).

Statistically significant differences in physical well-being and FACT-G and FACT-BMT subscale scores $(p<0.05)$ were observed for treatment/follow-up location. Scores were higher in outpatients who underwent hematopoietic stem cell transplantation than patients who had acute treatment in the hospital $(p<0.05)$ (Table 4$)$.

There were statistically significant differences between social life and family well-being, functional well-being, and FACT-G and FACT-BMT scores $(p<0.05)$ based on rehospitalization history. Scores of the patients who were not rehospitalized after discharge were higher than those of the patients who reported rehospitalization.

\section{Discussion}

4.1. Patient Symptoms. The cytotoxic agents used for immunosuppression during the treatment period of hematopoietic stem cell transplantation have side effects. These toxicities are temporary and include bone marrow depression, alopecia, mucositis, hemorrhagic cystitis, emesis, diarrhea, and negative effects on sexual life [16]. The most common symptoms, decrease in sexual function, hair loss, loss of taste, lack of appetite, and sleep disorders, are due to the posttransplantation treatment process and immunosuppressive treatment.

Increased symptom severity in patients with allogeneic hematopoietic stem cell transplantation was associated with poor quality of life and physical impairments [7, 10]. Fatigue, financial difficulty, and loss of appetite were the main problems experienced by hematopoietic stem cell transplant patients [17]. Allogeneic hematopoietic stem cell transplant survivors suffered mostly eye problems, dry mouth, cough, sexual problems, fatigue, anxiety, and changes in taste [18]. A study on a multiracial study population reported fatigue, pain, and insomnia to be the most common symptoms [17]. Another study reported that fatigue, sleep and sexual problems, emotional distress, and relationship difficulties were the main problems reported by patients who underwent allogeneic hematopoietic stem cell transplantation [13]. A study conducted in a hospital outpatient clinic on hematopoietic stem cell transplant patients after hospital discharge found that patients experienced psychological problems [19]. Another study conducted on Turkish hematopoietic stem cell 
TABLE 2: Symptoms experienced during treatment of patients who underwent hematopoietic stem cell transplantation $(n=100)$.

\begin{tabular}{|c|c|c|c|c|c|}
\hline \multirow{2}{*}{ Symptoms experienced during treatment } & Always & Mostly & Sometimes & Rarely & Never \\
\hline & $\%$ & $\%$ & $\%$ & $\%$ & $\%$ \\
\hline Hair loss & 43 & 23 & 15 & 12 & 7 \\
\hline Weight loss & 29 & 15 & 21 & 22 & 13 \\
\hline Constipation & 7 & 9 & 29 & 23 & 32 \\
\hline Diarrhea & 12 & 9 & 32 & 21 & 26 \\
\hline Loss of taste & 37 & 20 & 17 & 15 & 11 \\
\hline Headache & 13 & 8 & 22 & 26 & 31 \\
\hline Dizziness & 8 & 4 & 15 & 26 & 47 \\
\hline Itching & 10 & 2 & 21 & 23 & 44 \\
\hline Leg pain & 26 & 10 & 14 & 26 & 24 \\
\hline Myalgia & 19 & 5 & 22 & 23 & 31 \\
\hline Bone pain & 23 & 9 & 16 & 16 & 36 \\
\hline Sleep disorder & 27 & 23 & 18 & 10 & 22 \\
\hline Difficulty in concentrating & 28 & 12 & 14 & 13 & 33 \\
\hline Decrease in sexual functions & 59 & 11 & 10 & 7 & 13 \\
\hline Loss of appetite/anorexia & 33 & 22 & 15 & 15 & 15 \\
\hline Nausea, vomiting & 17 & 20 & 26 & 19 & 18 \\
\hline
\end{tabular}

transplant patients after discharge reported that psychological symptoms were more common than physical symptoms and that problems with sexual interest or activity, difficulty sleeping, and diarrhea were the most distressing symptoms [11]. Similar to previous studies, this study observed that patients who underwent hematopoietic stem cell transplantation commonly experienced the following symptoms: decreased sexual function, hair loss, loss of taste, lack of appetite, and sleep disorders. Collectively, these study results indicate that patients undergoing hematopoietic stem cell transplantation require support to address their emotional problems, fatigue, pain, body changes associated with hair loss, sexual problems, lack of appetite, and sleep disorders.

4.2. Patient Quality of Life. Hematopoietic stem cell transplantation affects different aspects of adult patients' social life as well as physical, family, emotional, and functional wellbeing. The potential effects also include intestinal problems, skin problems, vision defects, and sexual dysfunction. In the study by Grulke et al. (2012) patients who underwent hematopoietic stem cell transplantation had minimal quality of life during their treatment in the hospital. One year after transplantation, their quality of life had returned to normal levels; however, the patients reported continuing fatigue, dyspnea, and sleep disorders [20]. A study from Kisch et al. (2012) reported that all quality of life dimensions (except emotional well-being) deteriorated over 100 days following allogeneic hematopoietic stem cell transplantation [8]. Song and So (2015) found that the quality of life scores showed a decreasing tendency 100 days following hematopoietic stem cell transplantation [14]. Worse quality of life was especially pronounced in female patients and patients with complications associated with hematopoietic stem cell transplantation such as infection and graft-versus-host disease [8]. One qualitative study reported that patients experienced various physical limitations and changes in social roles and family and sexual life associated with allogeneic hematopoietic stem cell transplantation; concerns over bodily changes were also expressed by these patients [21]. Cohen et al. (2012) found that social interactions, sleep, and rest were the most negatively affected areas of well-being [7]. Another study found that the allogeneic hematopoietic stem cell transplantation survivors with high levels of distress over physical symptom had worse quality of life scores [10]. In the current study, quality of life was moderately affected in patients who had hematopoietic stem cell transplantation, primarily the physical well-being subscale. The physical well-being subscale scores indicate that the patients also had mild pain. Thus, patients may require more support to cope with pain and discomfort associated with treatment, as well as decreased energy and nausea.

It is noteworthy that social life and family well-being were the least affected aspects of quality of life in Turkish patients after hematopoietic stem cell transplantation. This finding indicates that Turkish patients had support during their treatment and adaptation to social life after transplantation. The family structure and cultural characteristics are likely the reason that the social life and family well-being subscale was the least affected area. Increasing social support for patients who have undergone hematopoietic stem cell transplantation is recommended to improve adaptation to treatment and resumption of normal life activities.

Based on the symptoms associated with hematopoietic stem cell transplantation, patient work life, enjoyment of life, acceptance of disease, and evaluation of the satisfaction with quality of life are important. The findings of this study revealed that transplantation patients' emotional well-being and functional well-being were moderately affected, which indicates that the patients did not receive sufficient support during their treatment and the process of transplantation to enable them to adapt to daily life activities and cope with 
TABLE 3: Means of FACT-BMT Scale following hematopoietic stem cell transplantation $(n=100)$.

\begin{tabular}{|c|c|c|}
\hline \multicolumn{2}{|c|}{$\begin{array}{l}\text { Functional Assessment of Cancer Therapy-Bone Marrow Transplant } \\
\text { (FACT-BMT) }\end{array}$} & \multirow{2}{*}{$\begin{array}{l}\text { Mean } \pm \text { SD } \\
2.43 \pm 1.26\end{array}$} \\
\hline \multirow{8}{*}{ Physical well-being } & I have a lack of energy & \\
\hline & I have nausea & $1.50 \pm 1.42$ \\
\hline & $\begin{array}{l}\text { Because of my physical condition, I have trouble } \\
\text { meeting the needs of my family }\end{array}$ & $2.85 \pm 1.47$ \\
\hline & I have pain & $2.08 \pm 1.54$ \\
\hline & I am bothered by side effects of treatment & $2.50 \pm 1.37$ \\
\hline & I feel ill & $2.15 \pm 1.43$ \\
\hline & I am forced to spend time in bed & $2.36 \pm 1.53$ \\
\hline & Physical well-being subscale & $12.13 \pm 6.88$ \\
\hline \multirow{8}{*}{ Social/family well-being } & I feel close to my friends & $2.66 \pm 1.13$ \\
\hline & I get emotional support from my family & $3.53 \pm 0.90$ \\
\hline & I get support from my friends & $3.17 \pm 1.07$ \\
\hline & My family has accepted my illness & $3.45 \pm 0.87$ \\
\hline & $\begin{array}{l}\text { I am satisfied with family communication about my } \\
\text { illness }\end{array}$ & $3.22 \pm 0.87$ \\
\hline & $\begin{array}{l}\text { I feel close to my partner (or the person who is my } \\
\text { main support) }\end{array}$ & $3.07 \pm 1.37$ \\
\hline & I am satisfied with my sex life & $0.94 \pm 1.21$ \\
\hline & Social/family well-being subscale & $20.81 \pm 4.26$ \\
\hline \multirow{7}{*}{ Emotional well-being } & I feel sad & $2.03 \pm 1.42$ \\
\hline & I am satisfied with how I am coping with my illness & $2.36 \pm 1.30$ \\
\hline & I am losing hope in the fight against my illness & $1.41 \pm 1.48$ \\
\hline & I feel nervous & $2.45 \pm 1.39$ \\
\hline & I worry about dying & $1.73 \pm 1.66$ \\
\hline & I worry that my condition will get worse & $2.04 \pm 1.60$ \\
\hline & Emotional well-being subscale & $12.70 \pm 6.41$ \\
\hline \multirow{9}{*}{ Functional well-being } & I am able to work (including work at home) & $1.08 \pm 1.24$ \\
\hline & My work (including work at home) is fulfilling & $1.07 \pm 1.21$ \\
\hline & I am able to enjoy life & $2.02 \pm 1.19$ \\
\hline & I have accepted my illness & $3.51 \pm 0.89$ \\
\hline & I am sleeping well & $2.23 \pm 1.38$ \\
\hline & I am enjoying the things I usually do for fun & $2.10 \pm 1.17$ \\
\hline & I am content with the quality of my life right now & $1.94 \pm 1.08$ \\
\hline & Functional well-being subscale & $13.95 \pm 4.61$ \\
\hline & FACT-G total score & $59.59 \pm 16.46$ \\
\hline
\end{tabular}


TABLE 3: Continued.

Functional Assessment of Cancer Therapy-Bone Marrow Transplant (FACT-BMT)

Bone Marrow Transplant Subscale (BMTS)

\begin{tabular}{lc} 
I am concerned about keeping my job (including work & $1.87 \pm 1.33$ \\
at home) & $1.79 \pm 1.38$ \\
I feel distant from other people & $1.50 \pm 1.43$ \\
I worry that the transplant will not work & $1.47 \pm 1.44$ \\
The side effects of treatment are worse than I had & $1.73 \pm 1.38$ \\
imagined & $1.96 \pm 1.15$ \\
I have a good appetite & $2.42 \pm 1.44$ \\
I like the appearance of my body & $2.59 \pm 1.35$ \\
I am able to get around by myself & $1.28 \pm 1.39$ \\
I get tired easily & $0.99 \pm 1.46$ \\
I am interested in sex & $3.62 \pm 0.63$ \\
I have concerns about my ability to have children & $0.52 \pm 0.87$ \\
I have confidence in my nurse(s) & $2.79 \pm 1.27$ \\
I regret having the bone marrow transplant & $2.50 \pm 1.27$ \\
I can remember things & $1.35 \pm 1.44$ \\
I am able to concentrate & $1.43 \pm 1.53$ \\
I have frequent colds/infections & $2.44 \pm 1.42$ \\
My eyesight is blurry & $1.33 \pm 1.44$ \\
I am bothered by a change in the way food tastes & $0.65 \pm 1.22$ \\
I have tremors & $1.49 \pm 1.51$ \\
I have been short of breath & $1.36 \pm 1.44$ \\
I am bothered by skin problems (e.g., rash, itching) & $2.47 \pm 1.42$ \\
I have trouble with my bowels & \\
My illness is a personal hardship for my close family & $2.63 \pm 1.44$ \\
members & \\
The cost of my treatment is a burden on me or my & $21.79 \pm 6.61$ \\
$\quad$ Bone Marrow Transplant Subscale (BMTS) & $47.87 \pm 15.49$ \\
TOI subscale & $81.38 \pm 21.91$ \\
\hline FACT-BMT total score & \\
\hline
\end{tabular}

PWB: physical well-being, SWB: social/family well-being, EWB: emotional well-being, FWB: functional well-being, BMTS: Bone Marrow Transplant Subscale, and TOI: FACT-BMT Trial Outcome Index.

Each item is measured from 0 to 4 . Possible range score for PWB is $0-28$, for SWB is $0-28$, for EWB is $0-24$, for FWB is $0-28$, for BMTS is $0-40$, for FACTBMT Trial Outcome Index (TOI) is 0-96, for FACT-G total score is 0-108, and for FACT-BMT total score is 0-148.

emotional problems. These patients should be encouraged to have hobbies, enjoy their lives, and deal with their sleep disorders. Sufficient support will result in increased acceptance and adaptation to the treatment process. Hematopoietic stem cell transplantation patients should be encouraged to express their feelings, emotions, and concerns and should be encouraged to consult a psychologist.

The BMTS subscale scores in this study indicate that patients require support for the following issues: appetite, physical well-being and problems associated with treatment process, memory status, blurred vision, and taste changes, skin-intestines problems, and difficulties that affect close relatives. Patients' ability to deal with these issues after discharge should be improved and training on managing symptoms should be provided to the patients and their families.
Nurses who work in this area have significant roles and responsibilities, from patient diagnosis to their quality of life after hematopoietic stem cell transplantation. Patients reported feeling highly satisfied with the care and support received during the acute period following allogeneic hematopoietic stem cell transplantation. They stated that safety, empathy, and encouragement during the treatment and care provided by the medical and nursing staff were important. Although transplant patients stated that they believed hematopoietic stem cell transplantation to be an effective treatment modality, they had some concerns for the future [22]. Patients who had hematopoietic stem cell transplantation were satisfied with their bone marrow transplantation therapy and reported relying on their nurses. These findings underscore the importance of patient trust 
TABLE 4: Comparison of FACT-BMT Scale means with patients' gender, family type, perceived health status, treatment, and history of rehospitalization following transplantation $(n=100)$.

(a)

\begin{tabular}{|c|c|c|c|c|c|}
\hline & Gender & $n$ & Mean \pm SD & $Z_{\mathrm{mwu}}$ & $p$ \\
\hline \multirow{2}{*}{ PWB } & Female & 46 & $11.26 \pm 7.19$ & \multirow{2}{*}{-1.229} & \multirow{2}{*}{0.22} \\
\hline & Male & 54 & $12.87 \pm 6.57$ & & \\
\hline \multirow{2}{*}{ SWB } & Female & 46 & $21.01 \pm 4.86$ & \multirow{2}{*}{-0.953} & \multirow{2}{*}{0.34} \\
\hline & Male & 54 & $20.64 \pm 3.71$ & & \\
\hline \multirow{2}{*}{ EWB } & Female & 46 & $10.39 \pm 6.33$ & \multirow{2}{*}{-3.262} & \multirow{2}{*}{$0.001^{* *}$} \\
\hline & Male & 54 & $14.67 \pm 5.84$ & & \\
\hline \multirow{2}{*}{ FWB } & Female & 46 & $13.78 \pm 4.63$ & \multirow{2}{*}{-0.392} & \multirow[t]{2}{*}{0.70} \\
\hline & Male & 54 & $14.09 \pm 4.64$ & & \\
\hline \multirow{2}{*}{ FACT-G } & Female & 46 & $56.45 \pm 17.58$ & \multirow{2}{*}{-1.768} & \multirow{2}{*}{0.08} \\
\hline & Male & 54 & $62.27 \pm 15.09$ & & \\
\hline \multirow{2}{*}{ BMTS } & Female & 46 & $20.70 \pm 6.15$ & \multirow{2}{*}{-1.431} & \multirow[t]{2}{*}{0.15} \\
\hline & Male & 54 & $22.72 \pm 6.89$ & & \\
\hline \multirow{2}{*}{ TOI } & Female & 46 & $45.74 \pm 15.24$ & \multirow{2}{*}{-1.215} & \multirow{2}{*}{0.225} \\
\hline & Male & 54 & $49.69 \pm 15.61$ & & \\
\hline \multirow{2}{*}{$\begin{array}{l}\text { FACT-BMT total } \\
\text { score }\end{array}$} & Female & 46 & $77.14 \pm 22.66$ & \multirow{2}{*}{-1.757} & \multirow{2}{*}{0.08} \\
\hline & Male & 54 & $84.99 \pm 20.79$ & & \\
\hline
\end{tabular}

(b)

\begin{tabular}{|c|c|c|c|c|c|}
\hline & Type of patient family & $n$ & Mean \pm SD & $\chi_{\mathrm{kw}}^{2}$ & $p$ \\
\hline \multirow{3}{*}{ PWB } & Elementary family & 73 & $12.56 \pm 7.02$ & \multirow{3}{*}{1.245} & \multirow{3}{*}{0.54} \\
\hline & Traditional, large family & 18 & $10.89 \pm 6.95$ & & \\
\hline & Broken family & 9 & $11.11 \pm 5.67$ & & \\
\hline \multirow{3}{*}{ SWB } & Elementary family ${ }^{(1)}$ & 73 & $20.33 \pm 4.02$ & \multirow{3}{*}{12.024} & \multirow{3}{*}{$0.002^{*}$} \\
\hline & Traditional, large family ${ }^{(2)}$ & 18 & $23.66 \pm 3.35^{(1,3)}$ & & \\
\hline & Broken family ${ }^{(3)}$ & 9 & $19.00 \pm 5.59$ & & \\
\hline \multirow{3}{*}{ EWB } & Elementary family & 73 & $12.22 \pm 6.43$ & \multirow{3}{*}{1.583} & \multirow{3}{*}{0.45} \\
\hline & Traditional, large family & 18 & $14.28 \pm 5.03$ & & \\
\hline & Broken family & 9 & $13.44 \pm 8.63$ & & \\
\hline \multirow{3}{*}{ FWB } & Elementary family & 73 & $13.73 \pm 4.86$ & \multirow{3}{*}{3.141} & \multirow{3}{*}{0.21} \\
\hline & Traditional, large family & 18 & $15.39 \pm 3.76$ & & \\
\hline & Broken family & 9 & $12.89 \pm 3.79$ & & \\
\hline \multirow{3}{*}{ FACT-G } & Elementary family & 73 & $58.84 \pm 16.34$ & \multirow{3}{*}{1.478} & \multirow{3}{*}{0.48} \\
\hline & Traditional, large family & 18 & $64.21 \pm 13.30$ & & \\
\hline & Broken family & 9 & $56.44 \pm 22.59$ & & \\
\hline \multirow{3}{*}{ BMTS } & Elementary family & 73 & $21.51 \pm 6.93$ & \multirow{3}{*}{2.455} & \multirow{3}{*}{0.29} \\
\hline & Traditional, large family & 18 & $23.61 \pm 6.16$ & & \\
\hline & Broken family & 9 & $20.44 \pm 4.16$ & & \\
\hline \multirow{3}{*}{ TOI } & Elementary family & 73 & $47.79 \pm 16.09$ & \multirow{3}{*}{0.818} & \multirow{3}{*}{0.66} \\
\hline & Traditional, large family & 18 & $49.89 \pm 14.84$ & & \\
\hline & Broken family & 9 & $44.44 \pm 12.15$ & & \\
\hline \multirow{3}{*}{$\begin{array}{l}\text { FACT-BMT total } \\
\text { score }\end{array}$} & Elementary family & 73 & $80.35 \pm 22.14$ & \multirow{3}{*}{1.392} & \multirow{3}{*}{0.50} \\
\hline & Traditional, large family & 18 & $87.82 \pm 18.56$ & & \\
\hline & Broken family & 9 & $76.89 \pm 25.96$ & & \\
\hline & Perceived health status & $n$ & Mean \pm SD & $\chi_{\mathrm{kw}}^{2}$ & $p$ \\
\hline \multirow{3}{*}{ PWB } & "Bad"(1) & 42 & $9.48 \pm 6.21$ & \multirow{3}{*}{11.39} & \multirow{3}{*}{$0.003^{* *}$} \\
\hline & "Moderate"(2) & 46 & $13.85 \pm 6.88^{(1)}$ & & \\
\hline & "Good"(3) & 12 & $14.83 \pm 6.38^{(1)}$ & & \\
\hline
\end{tabular}


(c) Continued.

\begin{tabular}{|c|c|c|c|c|c|}
\hline & Perceived health status & $n$ & Mean \pm SD & $\chi_{\mathrm{kw}}^{2}$ & $p$ \\
\hline \multirow{3}{*}{ SWB } & "Bad" & 42 & $20.54 \pm 4.26$ & \multirow{3}{*}{0.926} & \multirow{3}{*}{0.63} \\
\hline & "Moderate" & 46 & $20.95 \pm 4.09$ & & \\
\hline & "Good" & 12 & $21.24 \pm 5.14$ & & \\
\hline \multirow{3}{*}{ EWB } & "Bad" & 42 & $11.40 \pm 5.91$ & \multirow{3}{*}{3.357} & \multirow{3}{*}{0.19} \\
\hline & "Moderate" & 46 & $13.78 \pm 6.98$ & & \\
\hline & “Good" & 12 & $13.08 \pm 5.30$ & & \\
\hline \multirow{3}{*}{ FWB } & "Bad"(1) & 42 & $12.31 \pm 3.84$ & \multirow{3}{*}{10.992} & \multirow{3}{*}{$0.004^{* *}$} \\
\hline & "Moderate"(2) & 46 & $14.65 \pm 4.63^{(1)}$ & & \\
\hline & "Good"(3) & 12 & $17.00 \pm 5.10^{(1)}$ & & \\
\hline \multirow{3}{*}{ FACT-G } & "Bad"(1) & 42 & $53.73 \pm 13.81$ & \multirow{3}{*}{11.053} & \multirow{3}{*}{$0.004^{* *}$} \\
\hline & "Moderate"(2) & 46 & $63.24 \pm 16.68^{(1)}$ & & \\
\hline & "Good"(3) & 12 & $66.15 \pm 18.81^{(1)}$ & & \\
\hline \multirow{3}{*}{ BMTS } & "Bad" & 42 & $20.98 \pm 6.22$ & \multirow{3}{*}{2.788} & \multirow{3}{*}{0.25} \\
\hline & "Moderate" & 46 & $21.85 \pm 6.83$ & & \\
\hline & “Good" & 12 & $24.42 \pm 6.91$ & & \\
\hline \multirow{3}{*}{ TOI } & "Bad"(1) & 42 & $42.76 \pm 13.23$ & \multirow{3}{*}{10.230} & \multirow{3}{*}{$0.006^{* *}$} \\
\hline & "Moderate"(2) & 46 & $50.35 \pm 15.85^{(1)}$ & & \\
\hline & "Good"(3) & 12 & $56.25 \pm 16.63^{(1)}$ & & \\
\hline \multirow{3}{*}{$\begin{array}{l}\text { FACT-BMT total } \\
\text { score }\end{array}$} & "Bad"(1) & 42 & $74.70 \pm 18.67$ & \multirow{3}{*}{9.005} & \multirow{3}{*}{$0.011^{*}$} \\
\hline & "Moderate"(2) & 46 & $85.08 \pm 22.67^{(1)}$ & & \\
\hline & “Good"(3) & 12 & $90.57 \pm 24.49^{(1)}$ & & \\
\hline
\end{tabular}

(d)

\begin{tabular}{|c|c|c|c|c|c|}
\hline & Current treatment & $n$ & Mean \pm SD & $\chi_{\mathrm{kw}}^{2}$ & $p$ \\
\hline \multirow{3}{*}{ PWB } & Acute-phase treatment following transplantation ${ }^{(1)}$ & 59 & $10.22 \pm 6.61$ & \multirow{3}{*}{11.634} & \multirow{3}{*}{$0.003^{* *}$} \\
\hline & Outpatient follow-up ${ }^{(2)}$ & 29 & $15.21 \pm 5.93^{(1)}$ & & \\
\hline & Treatment of complications ${ }^{(3)}$ & 12 & $14.08 \pm 7.53$ & & \\
\hline \multirow{3}{*}{ SWB } & Acute-phase treatment following transplantation & 59 & $21.08 \pm 4.28$ & \multirow{3}{*}{1.63} & \multirow{3}{*}{0.44} \\
\hline & Outpatient follow-up & 29 & $20.86 \pm 4.27$ & & \\
\hline & Treatment of complications & 12 & $19.35 \pm 4.17$ & & \\
\hline \multirow{3}{*}{ EWB } & Acute-phase treatment following transplantation & 59 & $11.59 \pm 6.63$ & \multirow{3}{*}{5.095} & \multirow{3}{*}{0.08} \\
\hline & Outpatient follow-up & 29 & $14.97 \pm 5.74$ & & \\
\hline & Treatment of complications & 12 & $12.67 \pm 5.82$ & & \\
\hline \multirow{3}{*}{ FWB } & Acute-phase treatment following transplantation & 59 & $13.25 \pm 4.81$ & \multirow{3}{*}{4.218} & \multirow{3}{*}{0.12} \\
\hline & Outpatient follow-up & 29 & $15.48 \pm 4.01$ & & \\
\hline & Treatment of complications & 12 & $13.67 \pm 4.42$ & & \\
\hline \multirow{3}{*}{ FACT-G } & Acute-phase treatment following transplantation ${ }^{(1)}$ & 59 & $56.15 \pm 16.43$ & \multirow{3}{*}{7.073} & \multirow{3}{*}{$0.029^{*}$} \\
\hline & Outpatient follow-up ${ }^{(2)}$ & 29 & $66.52 \pm 14.57^{(1)}$ & & \\
\hline & Treatment of complications ${ }^{(3)}$ & 12 & $59.76 \pm 16.89$ & & \\
\hline \multirow{3}{*}{ BMTS } & Acute-phase treatment following transplantation & 59 & $20.36 \pm 6.61$ & \multirow{3}{*}{5.71} & \multirow{3}{*}{0.06} \\
\hline & Outpatient follow-up & 29 & $24.34 \pm 6.06$ & & \\
\hline & Treatment of complications & 12 & $22.67 \pm 6.32$ & & \\
\hline \multirow{3}{*}{ TOI } & Acute-phase treatment following transplantation ${ }^{(1)}$ & 59 & $43.83 \pm 15.40$ & \multirow{3}{*}{10.640} & \multirow{3}{*}{$0.005^{* *}$} \\
\hline & Outpatient follow-up ${ }^{(2)}$ & 29 & $55.03 \pm 12.98^{(1)}$ & & \\
\hline & Treatment of complications ${ }^{(3)}$ & 12 & $50.42 \pm 15.79$ & & \\
\hline
\end{tabular}


(d) Continued.

\begin{tabular}{|c|c|c|c|c|c|}
\hline & Current treatment & $n$ & Mean \pm SD & $\chi_{\mathrm{kw}}^{2}$ & $p$ \\
\hline \multirow{3}{*}{$\begin{array}{l}\text { FACT-BMT total } \\
\text { score }\end{array}$} & Acute-phase treatment following transplantation $^{(1)}$ & 59 & $76.51 \pm 21.92$ & \multirow{3}{*}{8.286} & \multirow{3}{*}{$0.016^{*}$} \\
\hline & Outpatient follow-up ${ }^{(2)}$ & 29 & $90.86 \pm 18.96^{(1)}$ & & \\
\hline & Treatment of complications ${ }^{(3)}$ & 12 & $82.43 \pm 22.50$ & & \\
\hline
\end{tabular}

(e)

\begin{tabular}{|c|c|c|c|c|c|}
\hline & History of hospitalization after transplantation & $n$ & Mean \pm SD & $Z_{\mathrm{mwu}}$ & $p$ \\
\hline \multirow{2}{*}{ PWB } & No & 62 & $12.68 \pm 7.01$ & \multirow{2}{*}{-0.956} & \multirow{2}{*}{0.34} \\
\hline & Yes & 38 & $11.24 \pm 6.65$ & & \\
\hline \multirow{2}{*}{ SWB } & No & 62 & $21.55 \pm 4.06$ & \multirow{2}{*}{-2.110} & \multirow{2}{*}{$0.035^{*}$} \\
\hline & Yes & 38 & $19.61 \pm 4.35$ & & \\
\hline \multirow{2}{*}{ EWB } & No & 62 & $13.45 \pm 6.13$ & \multirow{2}{*}{-1.362} & \multirow{2}{*}{0.17} \\
\hline & Yes & 38 & $11.47 \pm 6.74$ & & \\
\hline \multirow{2}{*}{ FWB } & No & 62 & $14.68 \pm 4.62$ & \multirow{2}{*}{-2.013} & \multirow[t]{2}{*}{$0.044^{*}$} \\
\hline & Yes & 38 & $12.76 \pm 4.40$ & & \\
\hline \multirow{2}{*}{ FACT-G } & No & 62 & $62.35 \pm 15.01$ & \multirow{2}{*}{-2.003} & \multirow{2}{*}{$0.045^{*}$} \\
\hline & Yes & 38 & $55.08 \pm 17.88$ & & \\
\hline \multirow{2}{*}{ BMTS } & No & 62 & $22.74 \pm 6.61$ & \multirow{2}{*}{-1.921} & \multirow{2}{*}{0.06} \\
\hline & Yes & 38 & $20.24 \pm 6.39$ & & \\
\hline \multirow{2}{*}{ TOI } & No & 62 & $50.10 \pm 15.45$ & \multirow{2}{*}{-1.851} & \multirow{2}{*}{0.06} \\
\hline & Yes & 38 & $44.24 \pm 15.05$ & & \\
\hline \multirow{2}{*}{$\begin{array}{l}\text { FACT-BMT total } \\
\text { score }\end{array}$} & No & 62 & $85.10 \pm 20.33$ & \multirow{2}{*}{-2.014} & \multirow{2}{*}{$0.044^{*}$} \\
\hline & Yes & 38 & $75.32 \pm 23.29$ & & \\
\hline
\end{tabular}

$\chi_{\mathrm{kw}}^{2}:$ Kruskal Wallis test; $Z_{\mathrm{mwu}}$ : Mann-Whitney $U$ test; ${ }^{*} p<0.05$ and ${ }^{* *} p<0.01$.

PWB: Physical well-being; SWB: social/family well-being; EWB: emotional well-being; FWB: functional well-being; BMTS: Bone Marrow Transplant Subscale; TOI: FACT-BMT Trial Outcome Index; FACT-G total score.

Each number refers to the order of the group of each variable. 1: first group: "elementary family group," "bad perceived health status group," and "acute-phase treatment following transplantation group"; 2: second group: "traditional, large family group," "moderate perceived health status group," and "outpatient follow-up group"; 3 : third group: "broken family group," "good perceived health status group," and "treatment of complications group."

in hematopoietic stem cell transplantation treatment. These are very important indications that patients believed that they received sufficient support during the transplantation process, were satisfied with the nursing, and appreciated the treatment and care.

4.3. Comparison of Average of Quality of Life Scores Based on Personal Characteristics. Many physical, emotional, and social well-being characteristics of patients who have undergone hematopoietic stem cell transplantation are affected by factors such as conditioning regimen, type of transplantation, and complications associated with transplantation. The results of the current study indicate that social life and family well-being of patients 50-59 years of age were more negatively affected than those of patients 60-69 years of age. This study also revealed that quality of life in the lower body was more negatively affected in younger patients. Study findings indicate that patients need increased social support with increasing age; these patients also require more support for physical problems associated with transplantation.

Functional difficulties associated with hematopoietic stem cell transplantation, changes associated with role performance, and emotional problems might occur depending on patient gender. Social functioning in male hematopoietic stem cell transplantation patients was affected more negatively than that of female patients [17]. Other studies found that female patients had more psychological problems such as depression [19] and poorer quality of life scores [8]. Another study reported depression to be a common problem in patients undergoing hematopoietic stem cell transplantation [9]. Similar to our study findings, emotional well-being is reportedly more affected in female patients. Based on these observations, female patients should be encouraged to express their feelings and receive emotional support.

Karacan (2006) found that married patients who had peripheral blood stem cell transplantation experienced more anxiety during the early hospitalization period and were more likely to experience depression after 30 days [3]. Unlike the findings reported by Karacan, the BMTS subscale scores in the current study were more negatively affected in single patients than in married patients. This result indicates that single patients require more support during transplantation and for problems associated with transplantation.

Song and So found that social addiction and loneliness negatively affect patient quality of life after allogeneic hematopoietic stem cell transplantation [14]. Similarly, the 
findings of the current study revealed that the social life and family well-being were more negatively affected in patients with elementary or broken families than in patients with large traditional families. These results suggest that family type affects quality of life and that wide social environment and sources of social support are important to successfully adapt. Thus, family structure and evaluation of social relationships are recommended in order to improve social support.

Perception of health status is a multidimensional concept covering physical activity, daily life activities, perception of the patients' health situation by the patients and the patients' communities, psychological well-being, and social activities [23]. Determining the perception of patients who have undergone transplantation regarding their health will contribute to improved care and treatment success during the transplantation process. A study reported that although patients who underwent allogeneic hematopoietic stem cell transplantation experienced various impairments in their functional status, most of them defined their health as quite good or excellent [18]. Most patients who underwent hematopoietic stem cell transplantation rated their quality of life as good or very good [17]. In this study, the quality of life of transplant patients who defined their health within the last year as "bad" were more adversely affected than those who defined their quality of life as "moderate" or "good." Thus, assessing the perceptions of health among transplant patients is essential in order to determine and meet their health needs with a holistic approach.

Patients with worse functional status and those who had complications associated with allogeneic hematopoietic stem cell transplantation had worse quality of life scores and more severe symptoms $[7,18,24]$. In this study, patients who returned to the hospital for treatment after hematopoietic stem cell transplantation had worse quality of life after discharge than those who had outpatient follow-up. This finding indicates that increased support is needed for physical complaints and functional and emotional well-being.

Allogeneic hematopoietic stem cell transplant patients are at high risk of complications and recurrent hospitalizations. Frequent monitoring and treatment adjustment may help to decrease the incidence of late complications. In a study on patients who underwent hematopoietic stem cell transplant, the majority of patients (83.3\%) did not report rehospitalization history after discharge [11]. Similarly, the results of the current study indicated that history of hospitalization more negatively affected patient quality of life. Patient social life and family well-being, functional well-being subscale, and total quality of life scores following discharge were significantly lower than the scores of patients who did not have hospitalization history after discharge following hematopoietic stem cell transplantation. Therefore, efforts should be made to improve social support and functional performance in rehospitalized patients.

There are many risk factors that influence the outcome after HSCT which were the type of disease, stage of the disease, the age of the patient, the time interval from diagnosis to transplant, and, for allo-HSCT, the donor/recipient histocompatibility [25]. If the autoimmune disease does not respond to approved therapy and progress cannot be stopped, clinicians should considered auto-HSCT [26, 27]. The report of European Society for Blood and Marrow Transplantation (2015) suggests adult patients with the underlying autoimmune diseases be considered as indications for auto-HSCT [25]. Auto-HSCT should be considered for patients with aggressive disease with poor outcomes. Auto-HSCT has been used as a rescue strategy and treatment for the autoimmune diseases with poor response to the established therapies for more than two decades. Stem cell transplantation has been offered for patients with autoimmune diseases, such as rheumatoid arthritis, Crohn's disease, multiple sclerosis, systemic lupus erythematosus, autoimmune cytopenia, and autoimmune cytopenias with either immune thrombocytopenia or autoimmune haemolytic anaemia. Overall 5-year survival and a progression-free survival have been reported to be high in autologous HSCT patients according to each ADspecific condition [25-27].

One-third of the sample (29\%) in the current study underwent autologous hematopoietic stem cell transplantation. Some patients underwent hematopoietic stem cell transplantation with the diagnosis of light chain deposition disease $(n=1)$ and autoimmune cytopenias $(n=4)$ and a few with severe immunodeficiencies $(n=5)$. In the current study, the number of patients who underwent auto-HSCT with the diagnosis autoimmune cytopenias was only four. Because of that, it not possible to make a conclusion for the quality of life of patients undergoing autologous HSCT with the diagnosis of autoimmune hematologic diseases. The outcomes of HSCT differ in patients undergoing autologous HSCT for autoimmune hematologic diseases. Studies are required on more selected patients with undergoing allogenic HSCT or autologous HSCT for the treatment of hematological malignancies.

\section{Conclusion}

The results of this study highlight the need for implementation of strategies to improve mean total scores and, consequently, quality of life of patients undergoing hematopoietic stem cell transplantation.

\section{Additional Points}

Relevance to Clinical Practice. Frequent screening and management of patient symptoms in order to help patients adapt to life following allogeneic hematopoietic stem cell transplantation are crucial for meeting care needs and developing strategies to improve the quality of life of transplant patients. One possible solution is to provide additional patient support regarding the transplantation process in terms of physi$\mathrm{cal} /$ body well-being, emotional problems, and management of symptoms during acute care after transplantation. Patients with chronic diseases and female patients should be observed closely for adverse emotional effects. Social support should be provided for patients undergoing hematopoietic stem cell transplantation, particularly female patients, single patients, and those aged 50-59 years, as well as patients with elementary or broken families, history of chronic diseases, and a reported history of rehospitalization after discharge. 


\section{Consent}

All participants gave informed consent for the research and their anonymity was preserved.

\section{Disclosure}

This manuscript has not been published before and is not being considered for publication elsewhere.

\section{Competing Interests}

The authors declare that they have no conflict of interests.

\section{Authors' Contributions}

Authors approve the content of the manuscript and have contributed significantly to research involved/the writing of the manuscript.

\section{Acknowledgments}

The authors wish to thank all the patients who participated into the study.

\section{References}

[1] Y. Karacan and S. Aksu, "Hematopoietic stem cell transplantation," in The Oncology Nursing, G. Can, Ed., pp. 229-239, Nobel Tip Kitabevleri, Istanbul, Turkey, 2014.

[2] Republic of Turkey Ministry of Health, "Hematopoietic Cell Transplantation Data System: 2015," March 2016, http://kemikiligi.saglik.gov.tr/Login.aspx?ReturnUrl=\%2f.

[3] Y. Karacan, Level of anxiety and depression in patients undergoing autologous and allogeneic stem cell transplantation [M.S. thesis], Hacettepe Üniversitesi Sağlik Bilimleri Enstitüsü. İç Hastalıkları Hemşireliği Programı, Yüksek Lisans Tezi, Ankara, Turkey, 2006.

[4] D. K. Gürel, A Study on life quality and related factors of patients who take chemotherapy in the units of adult oncology and hematology of Cukurova University, Faculty of Medicine, Balcalı Hospital [M.S. thesis], Çukurova Üniversitesi Sağlık Bilimleri Enstitüsü. Hemșirelik Anabilim Dalı, Yüksek Lisans Tezi, Adana, Turkey, 2007.

[5] Z. Mehrekula, Semptom management in hematologic malignancies [M.S. thesis], Ege Üniversitesi Sağlık Bilimleri Enstitüsü. İç Hastalıkları Hemşireliği Anabilim Dalı, Yüksek Lisans Tezi, İzmir, Turkey, 2010.

[6] S. Kapucu and N. Akdemir, "Ev ziyaretinin kemoterapi alan hastaların yaşam kalitesi ve öz-bakım güçlerine etkisi," Hacettepe Üniversitesi Hemşirelik Yüksekokulu Dergisi, vol. 17, pp. 9-22, 2007.

[7] M. Z. Cohen, C. L. Rozmus, T. R. Mendoza et al., "Symptoms and quality of life in diverse patients undergoing hematopoietic stem cell transplantation," Journal of Pain and Symptom Management, vol. 44, no. 2, pp. 168-180, 2012.

[8] A. Kisch, S. Lenhoff, S. Zdravkovic, and I. Bolmsjö, "Factors associated with changes in quality of life in patients undergoing allogeneic haematopoietic stem cell transplantation," European Journal of Cancer Care, vol. 21, no. 6, pp. 735-746, 2012.
[9] S. B. Artherholt, F. Hong, D. L. Berry, and J. R. Fann, "Risk factors for depression in patients undergoing hematopoietic cell transplantation," Biology of Blood and Marrow Transplantation, vol. 20, no. 7, pp. 946-950, 2014.

[10] M. F. Bevans, S. A. Mitchell, J. A. Barrett et al., "Symptom distress predicts long-term health and well-being in allogeneic stem cell transplantation survivors," Biology of Blood and Marrow Transplantation, vol. 20, no. 3, pp. 387-395, 2014.

[11] G. Oguz, S. Akin, and Z. Durna, "Symptoms after hospital discharge following hematopoietic stem cell transplantation," Indian Journal of Palliative Care, vol. 20, no. 1, pp. 41-49, 2014.

[12] I. Nar, Long term endocrinological complications of children and adolescents who have undergone hematopoietic stem cell transplantation [M.S. thesis], Hacettepe Üniversitesi, Çocuk Sağlığı ve Hastalıkları Anabilim Dalı, Uzmanlık Tezi, Ankara, Turkey, 2014.

[13] A. Poloméni, S. Lapusan, C. Bompoint, M. Rubio, and M. Mohty, "The impact of allogeneic-hematopoietic stem cell transplantation on patients' and close relatives' quality of life and relationships," European Journal of Oncology Nursing, vol. 21, pp. 248-256, 2016.

[14] C. E. Song and H. S. So, "Factors influencing changes in quality of life in patients undergoing hematopoietic stem cell transplantation: a longitudinal and multilevel analysis," Journal of Korean Academy of Nursing, vol. 45, no. 5, pp. 694-703, 2015.

[15] R. P. McQuellon, G. B. Russell, D. F. Cella et al., "Quality of life measurement in bone marrow transplantation: development of the functional assessment of cancer therapy-bone marrow transplant (FACT-BMT) scale," Bone Marrow Transplantation, vol. 19, no. 4, pp. 357-368, 1997.

[16] S. Z. Öz, Quality of life and chemotherapy treated patients with hematological malignancy [M.S. thesis], Marmara Üniversitesi Sağlık Bilimleri Enstitüsü İç Hastalıkları Hemşireliği Anabilim Dalı, Yüksek Lisans Tezi, Istanbul, Turkey, 2006.

[17] P. C. Bee, G. G. Gan, V. J. Sangkar, A. R. Haris, and E. Chin, "Quality of life after haematopoietic stem cell transplantation in a multiracial population," Medical Journal of Malaysia, vol. 66, no. 5, pp. 451-455, 2011.

[18] L. Edman, J. Larsen, H. Hägglund, and A. Gardulf, "Healthrelated quality of life, symptom distress and sense of coherence in adult survivors of allogeneic stem-cell transplantation," European Journal of Cancer Care, vol. 10, no. 2, pp. 124-130, 2001.

[19] V. DeMarinis, A. J. Barsky, J. H. Antin, and G. Chang, "Health psychology and distress after haematopoietic stem cell transplantation," European Journal of Cancer Care, vol. 18, no. 1, pp. 57-63, 2009.

[20] N. Grulke, C. Albani, and H. Bailer, "Quality of life in patients before and after haematopoietic stem cell transplantation measured with the European Organization for Research and Treatment of Cancer (EORTC) Quality of Life Core Questionnaire QLQ-C30," Bone Marrow Transplantation, vol. 47, no. 4, pp. 473-482, 2012.

[21] K. H. Nørskov, M. Schmidt, and M. Jarden, "Patients' experience of sexuality 1-year after allogeneic haematopoietic stem cell transplantation," European Journal of Oncology Nursing, vol. 19, no. 4, pp. 419-426, 2015.

[22] K. Bergkvist, J. Larsen, U.-B. Johansson, J. Mattsson, and B.-M. Svahn, "Hospital care or home care after allogeneic hematopoietic stem cell transplantation-patients' experiences of care and support," European Journal of Oncology Nursing, vol. 17, no. 4, pp. 389-395, 2013. 
[23] S. Arslan and N. Bölükbas, "Kanserli hastalarda yaşam kalitesinin değerlendirilmesi," Atatürk Üniversitesi Hemşirelik Yüksekokulu Dergisi, vol. 6, pp. 25-28, 2003.

[24] A. Barban, F. L. Coracin, P. T. Musqueira et al., "Analysis of the feasibility of early hospital discharge after autologous hematopoietic stem cell transplantation and the implications to nursing care," Revista Brasileira de Hematologia e Hemoterapia, vol. 36, no. 4, pp. 264-268, 2014.

[25] A. Sureda, P. Bader, S. Cesaro et al., "Indications for alloand auto-SCT for haematological diseases, solid tumours and immune disorders: current practice in Europe, 2015," Bone Marrow Transplantation, vol. 50, no. 8, pp. 1037-1056, 2015.

[26] M. Potter, C. Black, and A. Berger, "Bone marrow transplantation for autoimmune diseases," British Medical Journal, vol. 318, no. 7186, pp. 750-751, 1999.

[27] T. Hügle and T. Daikeler, "Stem cell transplantation for autoimmune diseases," Haematologica, vol. 95, no. 2, pp. 185-188, 2010. 


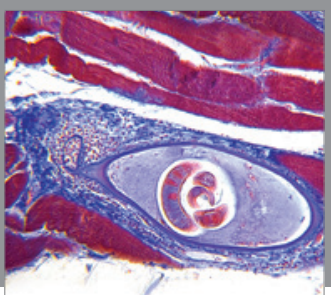

Gastroenterology

Research and Practice
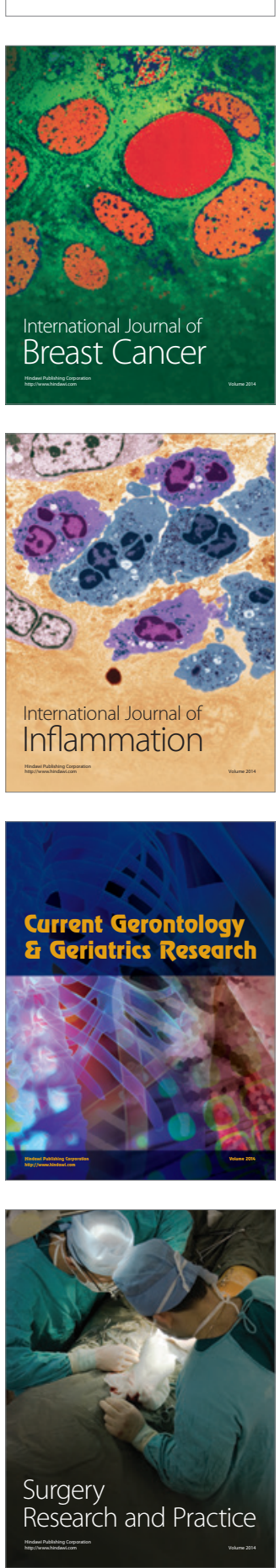

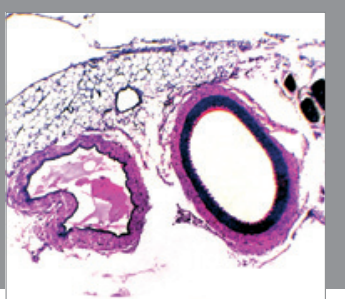

International Journal of Hypertension
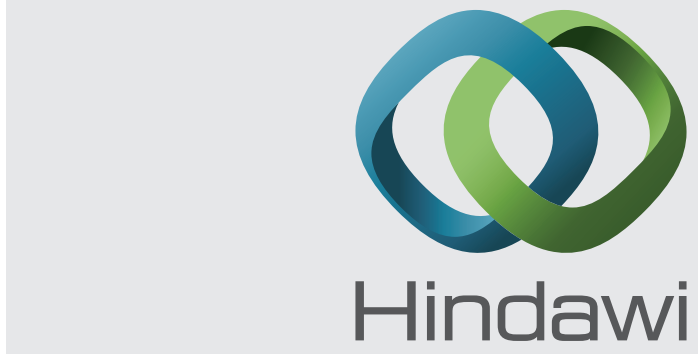

Submit your manuscripts at http://www.hindawi.com
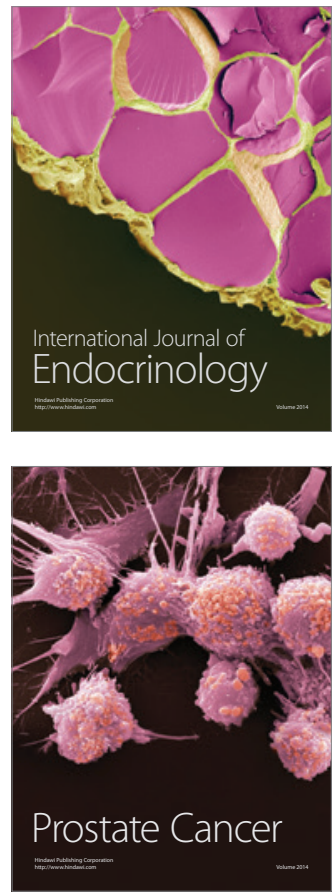

The Scientific World Journal
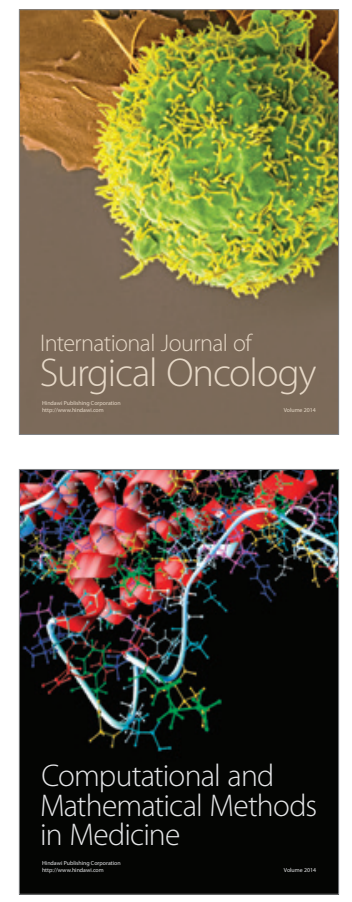
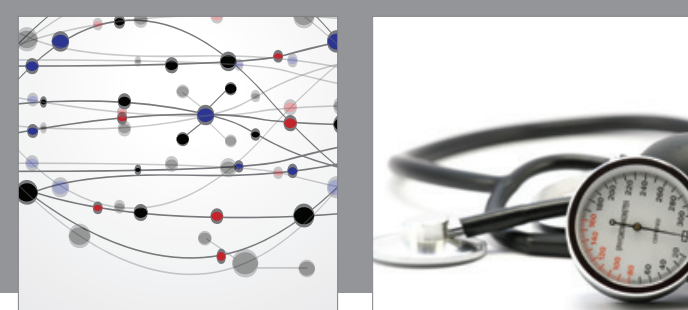

Nursing

Research and Practice

Research and Practice
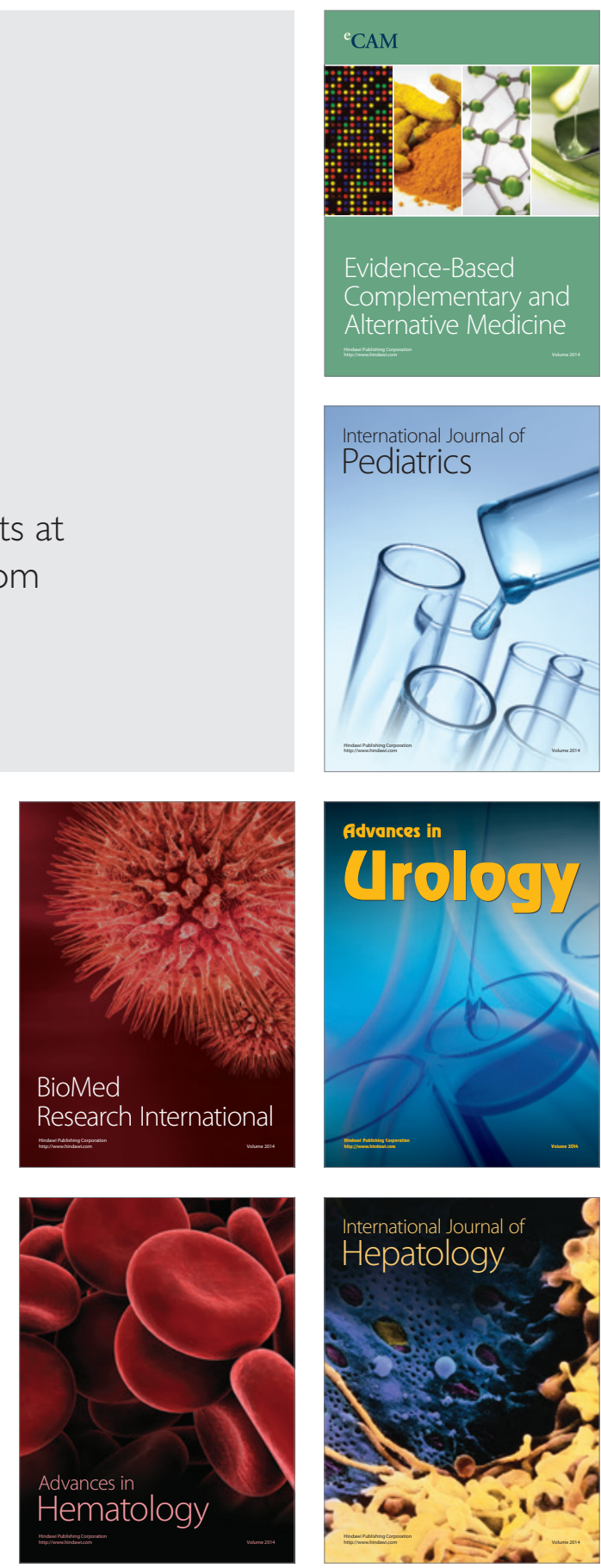
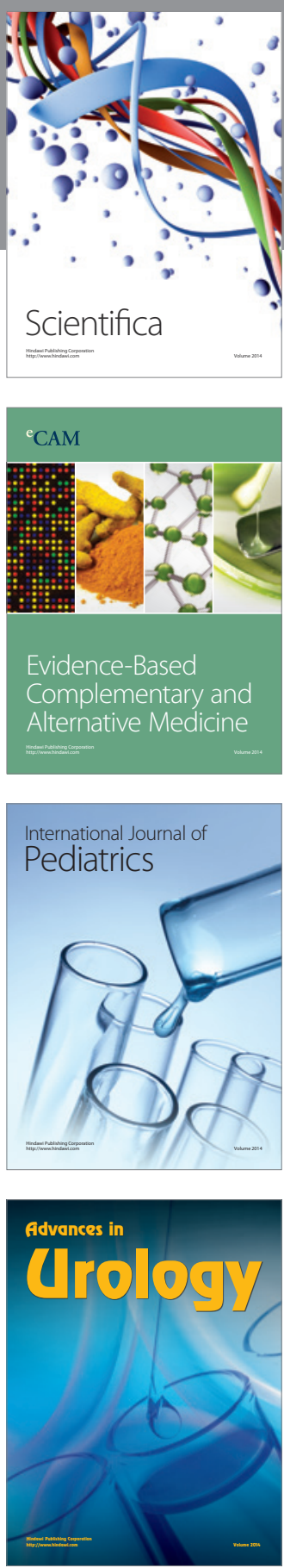

Scientifica

Evidence-Based

Complementary and

Alternative Medicine

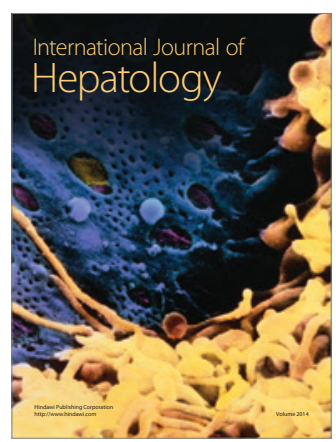

